\title{
A study on relationship between firm's financial performance and immediate and long-term stock return
}

\author{
Mohamad Sirani $^{\mathrm{a}}$, Mohamad Sadegh Taghavifardod ${ }^{\mathrm{b}^{*}}$ and Hasan Hemmati ${ }^{\mathrm{c}}$
}

${ }^{a}$ Assist. Prof. of Accounting, Department of Entrepreneurship, University of Tehran, Tehran, Iran

${ }^{b}$ M.Sc. of Accounting, School of Accounting, Kashan Branch, Islamic Azad University (IAU), Kashan, Iran

${ }^{c}$ Assist. Prof. \& Faculty Member, School of Raja, Gahazvin, Iran

\section{CHRON I CLE ABSTRACT}

Article history:

Received May 12, 2013

Received in revised format

25 June 2013

Accepted 27 June 2013

Available online

July 42013

Keywords:

Tehran Stock Exchange

Financial performance

Stock price performance

Past performance

\begin{abstract}
Previous studies show investors' overreaction towards firms past performance. In fact, investors overvalue past winners and undervalue past losers. However, when their expectations do not come true, stock prices return to their fair values. This study investigates investors' overreaction in Tehran Stock Exchange in three steps. Using a five-year period data collected from Tehran Stock Exchange (TSE), we evaluate portfolio performance and analyze them based on a sample of 70 firms selected from this exchange and, using Pearson correlation as well as regression analysis, examine the effects of past performance on price appreciation. The preliminary results indicate that TSE investors normally overreact to sale, quality of sale, operating profit, quality of profit, cash flow and stock return, significantly.
\end{abstract}

\section{Introduction}

There are always events on stock market when investors over-react on some news either positively or negatively (La Porta et al., 1997; Lee \& Swaminathan, 2000). In some circumstances, the shares of many companies may either over bought/sold and some analysts call it as irrational exuberance. When a sell-off happens on the market, it is important for investors to get out of market very quickly (Lakonishok et al., 1994; Jegadeesh \& Titman, 2001). In fact, it may take a long time for shares of some well-known firms to be appreciated substantially but a significant loss on stock prices may happen over a night. Therefore, it is important to learn more about investors' sentiment and minimize any bad consequences of market turbulences (Barberis et al., 1998, 2005).

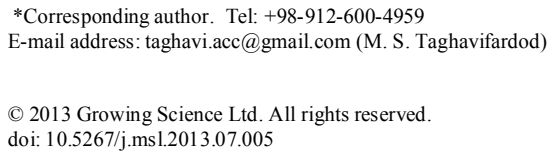


Evaluating the predictive capability of behavioral finance theories based on out-of-sample data plays essential role in investment decisions. Chan et al. (2004) examined pricing effects attributed to two psychological biases, representativeness and conservatism, which underlie various behavioral finance theories. They looked for the pricing consequences of representativeness and conservatism based on trends and consistency of accounting performance and reported some mixed evidences consistent with behavioral finance. Investors' psychology is another important issue, which may influence investment decisions (Daniel et al., 1998; Hirshleifer, 2001) and some market overreact could be because of investors' personal characteristics.

According to Bondth and Thaler (1985) and Zarowin (1989), research in experimental psychology recommends that, in violation of Bayes' rule, most people may overreact to unexpected news. They studied whether such behavior influences stock prices and reported substantial weak form market inefficiencies. Different studies recommend that a company distress risk factor could be behind the size and the book-to-market influences (Fama, 1998, 1991). According to Dichev (1998), if bankruptcy risk is systematic, one could anticipate a positive association between bankruptcy risk and subsequent realized returns. He reported that firms with high bankruptcy risk could earn lower than average returns since 1980 .

Fama and French (1993) introduced five common risk factors in the returns on stocks and bonds where there of them were associated with stock-market including an overall market factor and factors related to firm size and book-to-market equity. In addition, they introduced two bond-market factors including maturity and default risks. Stock returns have shared variation because of the stock-market factors, and they are associated with bond returns through shared variation in the bond-market factors. They specify that, except for low-grade corporates, the bond-market factors could capture the common variation in bond returns. Grinblatt and Moskowitz (2004) predicted stock price movements from past returns by looking into the role of consistency and tax-loss selling.

Ahmadi et al. (2013) presented a logistic regression model to measure risk management of receivable accounts on some selected firms from drug industry listed on Tehran Stock Exchange. They studied the effects of various variables such as current ratio, quick ratio, working capital on total assets and cash flow on economic value added. They reported that the proposed model of this paper was able of forecasting high profit firms with a probability of $87.5 \%, 58.62 \%$ was the likelihood of predicting less profitable firms and on average, the firm could forecast profitable firms for $75.54 \%$, successfully. There are many studies associated with investing on Tehran Stock Exchange. For instance, Hejazi and Rostamnejad (2013) examined relationship between conservatism on financial reports and risk of stock price crash. Hayatbakhsh and Maghariee (2013) performed a study on relationship between asymmetric information on dividend polices of companies listed in Tehran Stock Exchange.

According to Jegadeesh and Titman (1993), strategies which buy stocks that have performed well in the past and sell stocks that have performed poorly in the past produce significant positive returns over 3-12-month holding time. They found that the profitability of these strategies were not due to their systematic risk or to delayed stock price reactions to common factors. Nevertheless, part of the abnormal returns produced in the first year after portfolio formation dissipates in the following two years. They also reported a similar pattern of returns around the earnings announcements of past winners and losers.

In other survey, they evaluated different explanations for the profitability of momentum strategies documented in Jegadeesh and Titman (1993). The evidence indicated that momentum profits had continued in the 1990s, recommending that the original results were not a product of data snooping bias. They also investigated the predictions of recent behavioral models that propose that momentum profits were due to delayed overreactions that were eventually reversed. Their evidence provided some support for the behavioral models, but this support should be tempered with caution (Jegadeesh 
\& Titman, 1993). Ball and Kothari (1989) in other survey, performed an investigation on nonstationary expected returns by looking into implications for tests of market efficiency and serial correlation in returns.

De Bondt and Thaler (1990) is the basis for prediction of investors' psychology on purchasing stock shares over the long term. There are two assumptions with their work: first they assume that if investors overreact on stock price based on news, their return on investment could be predicted based on the past performance only. Second, maximum market change may not be on the favor of investors. They examined their hypothesis by testing on a sample data over the period 1926-1982 and set a portfolio, which consists of stocks which had done poorly in the past five years but had positive activity at time of study and reported a 19.6\% return, which was bigger than the average market.

Chan (1988) reported an abnormal return on the strategy of buying losers and selling winners in the stock market, a finding often interpreted as support for the market overreaction hypothesis. The survey explored an alternative interpretation of this evidence and reported that the risks of losers and winners were not constant. The estimation of the return of this strategy was, therefore, sensitive to the methods implemented. When risk changes were controlled for, they reported only small abnormal returns.

\section{The proposed study}

The proposed study of this paper attempts to find out how past performance influences future pricing strategy among investors on Tehran Stock Exchange. The main hypothesis of this survey is as follows,

Main hypothesis: The shares of firms with higher (lower) performance are over (under) priced and over the long term will preserve low (high) return.

This hypothesis consists of the following six sub-hypotheses,

1. The shares of firms with higher (lower) sales figures are over (under) priced and over the long term will preserve low (high) return.

2. The shares of firms with higher (lower) sales quality are over (under) priced and over the long term will preserve low (high) return.

3. The shares of firms with higher (lower) net profit are over (under) priced and over the long term will preserve low (high) return.

4. The shares of firms with higher (lower) net profit are over (under) priced and over the long term will preserve low (high) return.

5. The shares of firms with higher (lower) cash flow are over (under) priced and over the long term will preserve low (high) return.

6. The shares of firms with higher (lower) return are over (under) priced and over the long term will preserve low (high) return. 
The proposed study of this paper selects some firms from Tehran Stock Exchange whose shares were actively traded over the period of study. In our study, all firms had the same fiscal year; they all had must be listed prior to year 2005. The sample size is calculated as follows,

$$
n=\frac{N \times z_{\alpha / 2}^{2} \times p \times q}{\varepsilon^{2} \times(N-1)+z_{\alpha / 2}^{2} \times p \times q},
$$

where $N$ is the population size, $p=1-q$ represents the yes/no categories, $z_{\alpha / 2}$ is CDF of normal distribution and finally $\varepsilon$ is the error term. Since we have $p=0.5, z_{\alpha / 2}=1.96$ and $N=458$, the number of sample size is calculated as $n=70$.

In this survey, the average sales growth as well as return is calculated based on geometric mean of yearly sales and return growth, respectively. Quality of sales is dummay variable, which is equal to one when the firm has better profit margin and market share compared with its rival and zero, otherwise. Net profit is the amount of net earning before tax and unexpected cost reported on income statement. Cash flow is also calculated based on the following formula,

Cash Flow From Operating Activities = EBIT + Depreciation - Taxes

where EBIT states earning before interest and tax. The study uses regression analysis as well as Pearson correlation test to examine all hypotheses.

\section{The results}

In this section, we preset the results of our survey on testing various hypotheses of this paper. Table 1 summarizes the results of P-value and Pearson correlation test on all figures.

\section{Table 1}

The summary of testing various hypotheses

\begin{tabular}{lccccc}
\hline Growth in & Number & t-student & P-Value & Correlation & Result \\
\hline Sales & 70 & 0.03 & 0.03 & 0.467 & Confirmed \\
Quality of earnings & 70 & 0.01 & 0.035 & 0.455 & Confirmed \\
Profit & 70 & 0.03 & 0 & 0.621 & Confirmed \\
Quality of profit & 70 & 0 & 0.015 & 0.523 & Confirmed \\
Cash flow & 70 & 0 & 0.042 & 0.425 & Confirmed \\
Return & 70 & 0 & 0.016 & 0.483 & Confirmed \\
\hline Total & 70 & 0.028 & 0 & 0.587 & Confirmed \\
\hline
\end{tabular}

As we can observe from the results of Table 1, all sub-hypotheses of the survey have been confirmed and we can conclude that the shares of firms with higher (lower) performance are over (under) priced and over the long term will preserve low (high) return. The results also are confirmed for subhypotheses in terms of sales growth, quality of earnings growth, profit growth, quality of profit and cash flow growth.

\section{Conclusion}

In this paper, we have presented an empirical investigation to study the impact of past performance on firms' performance on Tehran Stock Exchange. The proposed study selected 70 firms from this exchange and using the mean of information tried to evaluate the effect of past performance in terms of sales growth, quality of earnings growth, profit growth, quality of profit and cash flow growth on future price evaluation. The results of our investigation have confirmed all our hypotheses, which 
means that the shares of firms with better performance in the past will most likely be more appreciated compared with shares of firms with weak performance in the past. However, investors need to note that past performance does not always gurantee future prosperity and investors need to take a closer look at change in technology, economic condition, etc. to make wiser decisions.

\section{References}

Ahmadi, M., Pouraghajan, A \& Salehnezhad, S. (2013). Performance measurement of receivable accounts' risk management: A case study of Tehran Stock Exchange. Management Science Letters , 3(6), 1593-1598.

Ball, R., \& Kothari, S.P. (1989). Non-stationary expected returns: Implications for tests of market efficiency and serial correlation in returns. Journal of Financial Economics, 25, 51-74.

Barberis, N., Shleifer, A., \& Vishny, R. (1998). A model of investor sentiment. Journal of financial economics, 49(3), 307-343.

Barberis, N., Shleifer, A., \& Vishny, R. W. (2005). A model of investor sentiment. Advances in Behavioral Finance, 2, 423-59.

Bondt, W. F., \& Thaler, R. (1985). Does the stock market overreact?. The Journal of finance, 40(3), 793-805.

Chan, K. C. (1988). On the contrarian investment strategy. Journal of Business, 147-163.

Chan, W. S., Frankel, R., \& Kothari, S. P. (2004). Testing behavioral finance theories using trends and consistency in financial performance. Journal of Accounting and Economics, 38, 3-50.

Daniel, K., Hirshleifer, D. \& Subrahmanyam, A. (1998). Investor psychology and security market under and over-reactions. Journal of Finance, 53, 1839-1885.

De Bondt, W. F., \& Thaler, R. H. (1990). Do security analysts overreact?. The American Economic Review, 52-57.

Dichev, I. D. (1998). Is the risk of bankruptcy a systematic risk? the Journal of Finance, 53(3), 1131-1147.

Fama, E. F. (1998). Market efficiency, long-term returns, and behavioral finance. Journal of financial economics, 49(3), 283-306.

Fama, E. F. (1991). Efficient capital markets: II. The journal of finance, 46(5), 1575-1617.

Fama, E. F., \& French, K. R. (1993). Common risk factors in the returns on stocks and bonds. Journal of financial economics, 33(1), 3-56.

Grinblatt, M., \& Moskowitz, T. J. (2004). Predicting stock price movements from past returns: The role of consistency and tax-loss selling. Journal of Financial Economics, 71(3), 541-579.

Hayatbakhsh, A \& Maghariee, A. (2013). A study on relationship between asymmetric information on dividend polices of companies listed in Tehran Stock Exchange. Management Science Letters, 3(7), 2089-2094.

Hejazi, R \& Rostamnejad, S. (2013). An investigation on the effects of conservatism on reducing risk of stock market investment: A case study of Tehran Stock Exchange. Management Science Letters , 3(7), 1885-1890.

Hirshleifer, D. (2001). Investor psychology and asset pricing. The Journal of Finance, 56(4), 15331597.

Jegadeesh, N., \& Titman, S. (1993). Returns to buying winners and selling losers: Implications for stock market efficiency. The Journal of Finance, 48(1), 65-91.

Jegadeesh, N., \& Titman, S. (2001). Profitability of momentum strategies: An evaluation of alternative explanations. The Journal of Finance, 56(2), 699-720.

Lakonishok, J., Shleifer, A., \& Vishny, R. W. (1994). Contrarian investment, extrapolation, and risk. The journal of finance, 49(5), 1541-1578.

La Porta, R., Lakonishok, J., Shleifer, A., \& Vishny, R. (1997). Good news for value stocks: Further evidence on market efficiency. Journal of finance, 859-874. 
Lee, C., \& Swaminathan, B. (2000). Price momentum and trading volume. The Journal of Finance, 55(5), 2017-2069.

Zarowin, P. (1989). Does the stock market overreact to corporate earnings information?. The journal of Finance, 44(5), 1385-1399. 